\title{
Working on Health Optimization: A Major Goal for Health Maintenance
}

David $\mathrm{IMB}^{1^{*}}$

${ }^{1}$ Clinical Nutrition Practitioner, Post-Graduate Program in Health Sciences, Universidade do Sul de Santa Catarina, Av. Pedra Branca, Brazil

Corresponding Author: Isabela M. B. David, MD

Address: Clinical Nutrition Practitioner, Post-Graduate Program in Health Sciences, Universidade do Sul de Santa Catarina, Av. Pedra Branca, 25. Palhoça SC, 88137-270, Brazil; E-mail: contato.isabeladavid@gmail.com

Received date: 01 February 2020; Accepted date: 26 March 2020; Published date: 06 April 2020

Citation: David IMB. Working on Health Optimization: A Major Goal for Health Maintenance. Asp Biomed Clin Case Rep. 2020 Apr 6;3(1):87-89.

Copyright (C) 2020 David IMB. This is an open-access article distributed under the Creative Commons Attribution License, which permits unrestricted use, distribution, and reproduction in any medium provided the original work is properly cited.

Some years ago - let's say, for sure, some decades ago - a "good physician" was considered the one who would request a few laboratory tests to some patient and they would come out all altered. - Yes - one would say - he got it right to the point, disease concerning. However, in the $21^{\text {st }}$ century, when we have moved the focus of preventive care from prevention of diseases to health maintenance, we believe that the "good physician" may be considered the one that aims at keeping all the test results basically normal. Actually, more than that: optimal. In fact, keeping the eyes on optimal test results is a major goal for Age Management practitioners. For that, even if we still have the established reference ranges, we've got to have our own interpretation of the tests we are used to from a different, more detailed standpoint than in the general practice. Some normal results must be seen as subnormal, which are, indeed, still different from abnormal. Some results may also be considered critical - that is, those ones which demand some urgent and immediate action.

\section{A Personal Interpretation of Laboratory Tests in Age Management}

Working as a clinical nutrition practitioner - but one that has developed some ideas on Age Management since 2005 when I came across an article by Paolo Giacomoni (PhD) on Ageing [1]. I recently had a new patient who had a history of HbA1c levels at $5,6 \%$ in 2008 , but nothing was told him over the period of 11 years. I mean, he was not instructed on how to improve his condition before having diabetes utterly manifested in 2019 with HbA1c levels at 7,9\%. Presumably, an Age Management Medicine practitioner would have worked on getting his HbA1c levels down do normal/ optimal levels from the first meeting in 2008 and he would never have become diabetic. That's the idea.

Let's have a look on some examples:

\section{1) HbA1c (glycated hemoglobin) Test (\%)}

HbA1c is a marker of long term oxidative stress and reflects the levels of glycation in the blood. According to Barry Sears, PhD, a leading authority on the dietary control of hormonal and inflammatory responses and considered the founder of antiinflammatory nutrition, the ideal range is between 4,9 - 5,1\%. This corresponds to an estimated blood sugar level of $90-95 \mathrm{mg} / \mathrm{dl}$. In any case, it is important to make known to all patients, regardless of his/her HbA1c levels, how to avoid glycation with the right choice of foods and, possibly, some dietary supplements. But, considering that not always we will get the patient's attention in non-risky situations, we've got to have a straightforward approach to know exactly what to do in each case. 
Citation: David IMB. Working on Health Optimization: A Major Goal for Health Maintenance. Asp Biomed Clin Case Rep. 2020 Apr 6;3(1):87-89.

\section{Commentary}

One important recommendation to be considered is: total dietary carbohydrate (kcal) / total dietary protein (kcal) must be $\leq 1.3$ (40/30). That's because there is a specific anti-inflammatory diet for insulin control that proposes a macronutrient composition of $40 \%$ of the energy from carbohydrate, and 30\% of the energy each from protein and fat $[2,3]$. It is considered a low glycemic load diet [2]. Below you can see how I interpret $\mathrm{HbA} 1 \mathrm{c}$ test results in my clinical practice (Table-1).

Therefore, a precise approach is always needed to bring the patient's results to the optimal range. Emphasis must be given if HbA1c levels are $\geq 5,5$. Another way of looking into it is (Table-2):

\section{2) Ultrasensitive C-reactive Protein or CRP} ( $\mathrm{mcg} / \mathrm{mL})$
With ultrasensitive CRP - a biomarker of inflammation in different clinical settings, but, in our context, in relation to cardiovascular risk $[4,5]$ - the same "look" into the results can be made by Age Management Medicine practitioners, regardless of the references given by the laboratory where the test was taken. Once again, the ideal situation is to make known to all patients that low levels of inflammation are needed for health maintenance. But, let's make some similar risk management approach (Table-3):

In this case, ultrasensitive $\mathrm{CRP} \geq 1,0 \mathrm{mcg} / \mathrm{mL}$ requires some objective action with emphasis on an anti-inflammatory diet and supplements [6] to avoid getting to $\geq 3 \mathrm{mcg} / \mathrm{mL}$, what is associated with adverse cardiovascular risk [5]. However, to reach the optimal range must be the major goal.

\begin{tabular}{|l|l|}
\hline \multicolumn{1}{|c|}{ Test Results } & \multicolumn{1}{|c|}{ Table-1: HbA1c test results } \\
\hline Test result 4,9 to $5,1 \%$ (optimal) & He/she is doing fine. \\
\hline Test result 5,2 to $5,4 \%$ (normal) & $\begin{array}{l}\text { He/she is doing fine, but I will try to identify in which situation glycation is } \\
\text { happening and get HbA1c levels down to the optimal range. }\end{array}$ \\
\hline Test result 5,5 to $5,6 \%$ (subnormal) & $\begin{array}{l}\text { He/she must be alert that things are not working fine and, if glycation } \\
\text { continues rising up, he/she will get into the risk area. Glycation must be } \\
\text { reversed, with HbA1c levels falling down ideally to the optimal range. }\end{array}$ \\
\hline Test result 5,7 to 6,4\% (risk or critical area) & $\begin{array}{l}\text { The importance of immediate treatment has to be made clear to the patient } \\
\text { and appointments on a regular basis must be proposed until the results fall } \\
\text { down progressively, ideally to the optimal range. }\end{array}$ \\
\hline Test result $\geq 6,5$ (diabetes mellitus): & $\begin{array}{l}\text { Disease established and all the damage associated with it urge the patient's } \\
\text { unconditional commitment to reverse HbA1c levels, ideally to the optimal } \\
\text { range. }\end{array}$ \\
\hline
\end{tabular}

\begin{tabular}{|c|c|c|c|c|}
\hline \multicolumn{5}{|c|}{ Table-2: HbA1c (\%) } \\
\hline Optimal & \multicolumn{1}{|c|}{ Normal } & Subnormal & Critical & Diseased \\
\hline $4,9-5,1$ & $5,2-5,4$ & $5,5-5,6$ & $5,7-6,4$ & $\geq 6,5=$ diabetes \\
\hline
\end{tabular}

\begin{tabular}{|c|c|c|c|c|}
\hline \multicolumn{5}{|c|}{ Table-3: Ultrasensitive-CRP (mcg/mL) } \\
\hline Optimal & Normal & Subnormal & Critical & Elevated \\
\hline$<012$ & $0,12-0,99$ & $1,0-1,99$ & $2,0-2,99$ & $\geq 3$ \\
\hline
\end{tabular}


Citation: David IMB. Working on Health Optimization: A Major Goal for Health Maintenance. Asp Biomed Clin Case Rep. 2020 Apr 6;3(1):87-89.

\section{Commentary}

\begin{tabular}{|c|c|c|c|c|}
\hline \multicolumn{5}{|c|}{ Table-4: Vitamin B12 (cobalamine) levels $(\mathrm{pg} / \mathrm{mL})$} \\
\hline Diseased $^{*}$ & Critical & Subnormal & Normal & Optimal \\
\hline$<300$ & $300-399$ & $400-499$ & $500-599$ & $\geq 600-900$ \\
\hline
\end{tabular}

*The reference number which defines vitamin B12 deficiency changes between laboratories and researchers. In our case, we considered vitamin B12 deficiency levels below $300 \mathrm{pg} / \mathrm{mL}[7,8]$.

\section{3) Vitamin B12 (cobalamine) Levels ( $\mathrm{pg} / \mathrm{mL}$ )}

As far as vitamin B12 levels are concerned, we should work on to get optimal levels, that is, $\geq 600$ upto $900 \mathrm{pg} / \mathrm{mL}$, with emphasis if the levels are below $500 \mathrm{pg} / \mathrm{mL}$ (Table-4).

In conclusion, I believe that, in the long run, Age Management Medicine Group should work objectively to have a consensus on optimal/ normal/ subnormal/ critical/ diseased test levels, encouraging all practitioners to aim at optimal test results for health maintenance, although normal range may be acceptable. On the contrary, subnormal and critical levels should never be accepted and, the closer to the diseased level, more emphasis should be given to the treatment. Finally, systematic control of test results with a clear and specific timetable for checking the evolution of the treatment is certainly a must for Age Management Medicine practitioners.

\section{References}

[1] Giacomoni PU. Ageing, science and the cosmetics industry. The micro-inflammatory model serves as a basis for developing effective anti-ageing products for the skin. EMBO Rep. 2005 Jul;6 Spec No:S45-48. [PMID: 15995662]

[2] Bell SJ, Sears B. A proposal for a new national diet: a low-glycemic load diet with a unique macronutrient composition. Metab Syndr Relat Disord. 2003 Sep;1(3):199-208. [PMID: 18370663]

[3] Sears B. Anti-inflammatory Diets. J Am Coll Nutr. 2015;34 Suppl 1:14-21. [PMID: 26400429]

[4] Black S, Kushner I, Samols D. C-reactive protein. Journal of Biological Chemistry. 2004 Nov 19;279(47):48487-9o.

[5] Kop WJ, Weinstein AA. C-reactive Protein. 2007:653-58.

[6] Sears B, Bell S. The zone diet: an anti- inflammatory, low glycemic-load diet. Metab Syndr Relat Disord. 2004 Spring;2(1):24-38. [PMID: 18370674]

[7] Ko SH, Ko SH, Ahn YB, Song KH, Han KD, Park YM, Ko SH, Kim HS. Association of vitamin B12 deficiency and metformin use in patients with type 2 diabetes. J Korean Med Sci. 2014 Jul;29(7):965-72. [PMID: 25045229]

[8] Sheng X, Wang J, Li F, Ouyang F, Ma J. Effects of dietary intervention on vitamin B12 status and cognitive level of 18-month-old toddlers in highpoverty areas: a cluster-randomized controlled trial. BMC Pediatr. 2019 Sep 13;19(1):334. [PMID: 31519167] 